\title{
EXPLORING BUSINESS MODELS OF NONPROFIT ORGANIZATIONS
}

\author{
Julia Perić ${ }^{*}$ \\ Anamarija Delic ${ }^{* *}$ \\ Marina Stanic ${ }^{* * *}$
}

Received: 22.7 .2020

Preliminary communication

Accepted: 2. 12. 2020

UDC 005:061

DOI: https://doi.org/10.30924/mjcmi.25.2.10

\begin{abstract}
Business models are usually used to describe how business entities sustain their competitive advantage, offer their customers better value and create good cooperation with their partners. While the literature is rich with best practice examples among for-profit business entities, nonprofit organizations (NPOs) are rarely observed and compared through the business model concept. Nonprofit organizations are mostly viewed as mission-driven organizations, which is why the business side is often rather neglected. The success of nonprofit organizations is usually measured by their impact in the community, which makes their activities dynamic and very much dependable on their business ecosystem. The goal of this paper is to identify specific characteristics of business models in the nonprofit
\end{abstract}

Abstract

\section{INTRODUCTION}

The importance of nonprofit organizations for the development of society is unquestionable. Focusing on the mission sector, to evaluate how well nonprofit organizations communicate their value proposition to their customers, what distinguishes them from other nonprofits and what they are doing to develop a successful and sustainable organization. The empirical study covers ten Croatian nonprofit organizations. The business model canvas is used to describe and compare their business models. The findings represent a good basis for understanding the performance of nonprofit organization, and can serve as a framework for specific policies and programs aimed at development of nonprofit organizations.

Keywords: business models, nonprofit organizations, social mission, value proposition, case study

helps them address social issues, which the institutions responsible for solving them do not know how to tackle or cannot tackle. However, what is questionable is the sustainability of their ideas, values

\footnotetext{
* Julia Perić, PhD, Associate professor, J.J. Strossmayer University of Osijek, Faculty of Economics in Osijek, Trg Lj. Gaja 7, 31000 Osijek, Croatia, Phone +385 31/224-400, Fax +385 31/211-604, E-mail: julia.peric@efos.hr, ORCID: https://orcid.org/0000-0001-8031-743

** Anamarija Delić, PhD, Associate professor, J.J. Strossmayer University of Osijek, Faculty of Economics in Osijek, Trg Lj. Gaja 7, 31000 Osijek, Croatia, Phone +385 31/224-400, Fax +385 31/211-604, E-mail: anamarija. delic@efos.hr, ORCID: https://orcid.org/0000-0003-4808-7080

${ }^{* * * *}$ Marina Stanić (corresponding author), PhD, Assistant professor, J.J. Strossmayer University of Osijek, Faculty of Economics in Osijek, Trg Lj. Gaja 7, 31000 Osijek, Croatia, Phone +385 31/224-400, Fax +385 31/211-604, E-mail: marina.stanic@efos.hr, ORCID: https://orcid.org/0000-0002-3835-6358
} 


\section{Journal of Contemporary Management Issues}

and missions. Alfirević et al. (2014) argue that, from the aspect of funders, it is very important to know how successful an organization is in accomplishing goals, with the resources provided, which creates a need for efficiency ranking of nonprofits. Their performance is, usually, quite different from the standard economic performance of the companies - they rarely have the access to equity capital, they do not distribute resources to owners and they lack the systematic knowledge on the organizational effects of incorporating business practices into NPO's dayto-day performance (Helmig et.al, 2004; Suykens et.al, 2018).

In most countries, including Croatia, economic activity of nonprofit organizations is legally regulated, i.e. nonprofit organizations offer their products/services to the market. However, many nonprofit organizations in Croatia are still focusing on donations, sponsorships or different types of tenders, due to a lack of transparency and clear explanations of opportunities for economic activity. The issue of sustainability and dependence on different external sources of funding are obstacles for accomplishing the goals in almost all nonprofit organizations, as well as the most common reason for changing the business concept. Reluctance to adopt profit-oriented practices is particularly visible in marketing operations. Many nonprofit organizations tend to have an "organization-centred" mindset (as opposed to "customer-centred"), when it comes to marketing activities, carried out to support the funding segment. According to the study, conducted by Dolnicar and Lazarevski (2009), majority of marketing staff in nonprofit organizations are not trained, which results in marketing activities that do not include market research, or do not incorporate strategic marketing procedures, and are predominantly promotional in nature. Similar conclusions can be derived about nonprofit organizations in Croatia. Najev Čačija (2016) provided empirical evidence that highlights the need for the strategic marketing approach and implementation of the processes that will ensure continuous improvements, based on the organizational feedback and learning mechanisms.

Although the very term "business models" is almost completely unknown to nonprofit organizations, many of them, just like for-profit organizations, base their operations on business models, through which, the values they advocate and the resources they possess are directed towards achieving the organization's goals. The topic of business models of nonprofit organizations is an almost completely scientifically unexplored area. This paper seeks to answer two research questions: a) to what degree is the business model canvas, which is most commonly applied to for-profit organizations (developed by Osterwalder, Pigneur and Tucci, 2005) also applicable to nonprofit organizations and $b$ ) which parts of the business model should be adapted to the specifics of nonprofit organizations. The paper is structured in three parts. The first part consists of a literature review related to business models in general and business models of nonprofit organizations. The second, empirical part, critically analyses data obtained through in-depth research of ten nonprofit organizations from Croatia. In the third and final part, an overview of trends with which nonprofit organizations are and will be faced in the future, and in the conclusion answers to research questions, as well as implications for future research are given. 


\section{THEORETICAL FRAMEWORK OF BUSINESS MODELS}

The concept of a business model is not new, but it still lacks theoretical grounding in economics, or in business studies (Teece, 2010). The first definitions of the term can be found in the work of Konczal (1975), who provided the very first indication of the concept. After this study, only occasional usage of the term and concept can be found in the literature (Wirtz, 2011). The first attempts at formulating the concept, usually related to the technological and innovation orientation were developed in the period between 1997 and 2002, by a number of authors (Treacy and Wiersema, 1997; Timmers, 1998, Wirtz and Kleineicken, 2000; Hamel, 2000; Eriksson and Penker, 2000; Amit and Zott, 2001; Magretta, 2002; Hedman and Kalling, 2003). In that period, through "several critical articles" (Wirtz, 2011,p. 7) the firsts concepts of the business model have been developed. The business models were seen as "the interaction of operating processes, management systems, organizational structures and corporate culture" (Treacy and Wieserma, 1997, p. 10) and "stories that explain how enterprises work" (Magretta, 2002). The business model concept and the definition were strongly connected with strategic management and observed as "causally related components". Although thoroughly analyzed, the term and the concept of a business model are still relatively poorly understood (Linder and Cantrell, 2000). In literature, authors tend to use terms "strategy" and "business model" interchangeably (Magretta, 2002). While strategy includes execution and implementation, a business model is more about how a business works as a system. Osterwalder et al. (2005) claim that the topic of business models is often discussed superficially, without understanding of its roots, its role, and particularly its potential. The main role of the business model is to find and design a promising business concept (Osterwalder et al., 2005).

Hedman and Kalling (2003) developed a business model that started at the product market level - customers, competitors, offering, activities and organization, resources and factor and production input suppliers. They concluded that the model can be completed only with the introduction of managerial and organizational processes that should highlight cognitive, cultural, learning and political constraints. Afuah and Tucci (2003, p. 3) defined a business model through the firm's performance, where it stands for "the methods by which a firm builds and uses its resources to offer its customers better value than its competitors and to make money doing so". A business model enables the firm to obtain sustainable competitive advantage and can be "conceptualized as a system that is made up of components, linkages between the components and dynamics" (Afuah and Tucci, 2003). A business model is "a conceptual tool containing a set of objects, concepts and their relationships with the objective to express the business logic of a specific firm" (Osterwalder et al., 2005). The concept and the definition of a business model have evolved in course of the last ten years and the results have yielded a generic approach and synthesis of the existent literature (Wirtz, 2011). Afuah and Tucci (2003) conclude that business models consist of customer value, design scope, price setting, revenue sources, connected activities, implementation, capabilities and sustainability. The performance of the firm's business model will be strongly influenced by ICT and environment. 


\section{Journal of Contemporary Management Issues}

According to Osterwalder et al. (2005), the business model "serves as a building plan that allows designing and realizing the business structure and systems that constitute the company's operational and physical form". Since business models are subject to external pressure, there is a need for their constant change and adaptation. The main role of the business model is to help managers "to capture, understand, communicate, design, analyse and change the business logic of the firm" (Osterwalder et al., 2005). According to Linder and Cantrell (2000), the business model concept is usually not clearly communicated. This is the main reason why generic and shared concepts for describing business models became necessary. Teece (2010) concludes that criteria that enable evaluation of a business model must be identical across sectors. Considering the place of business models in economic theory, Williamson (1980) finds it an important interdisciplinary topic. A business model has to articulate the logic, data and other evidence that support the value a company offers to its customers (Teece, 2010). Research of business models has yielded several solutions that could explain business models in different companies.

Table 1. Elements of the business model according to different authors

\begin{tabular}{|l|l|}
\hline Author/s & Elements of the business model \\
\hline Treacy and Wieserma (1997) & $\begin{array}{l}\text { Operating processes, management systems, organizational structures, } \\
\text { corporate culture, customer value, customer benefit, infrastructure, } \\
\text { environment }\end{array}$ \\
\hline Timmers (1998) & $\begin{array}{l}\text { Products, services and information flows, description of various business } \\
\text { actors and their roles, potential benefits, sources of revenues }\end{array}$ \\
\hline Hamel (2000) & Core strategy, strategic resources, customer interface, value network \\
\hline Rayport and Jaworski (2001) & $\begin{array}{l}\text { Value proposition, marketplace offering, resource system and financial } \\
\text { model }\end{array}$ \\
\hline Hedman and Kalling (2002) & $\begin{array}{l}\text { Customers, competitors, offering, activities and organization, resources, } \\
\text { factor and production inputs, suppliers and managerial processes }\end{array}$ \\
\hline $\begin{array}{l}\text { Osterwalder, Pigneur and Tucci } \\
\text { (2005) }\end{array}$ & $\begin{array}{l}\text { 4 pillars: product, customer interface, infrastructure management and } \\
\text { financial aspects elaborated in 9 building blocks }\end{array}$ \\
\hline $\begin{array}{l}\text { Johnson, Christensen and } \\
\text { Kagermann (2008) }\end{array}$ & $\begin{array}{l}\text { Customer value proposition, profit formula, key resources and key } \\
\text { processes }\end{array}$ \\
\hline
\end{tabular}

Source: Adapted from Wirtz, B. (2011) Business model management, Design-Instruments-Success Factors, Gabler, Wiesbaden

Different views and proposed definitions of business models enable better understanding of the phenomenon, but limit the possibility of comparison and evaluation of their effectiveness. According to Osterwalder et al. (2005), the mail goal is should be to understand and share, to analyze, to manage and patent the business model. Building upon pillars that were grounded in previous research results, Osterwalder et al. (2005) developed a business model canvas that consists of 9 building blocks. This canvas provides a necessary basis for comparison of different business models across industries, and is widely accepted as the model that captures all data needed for describing the way a company is competing on the market and captures the value. 
Table 2. Nine business model elements

\begin{tabular}{|l|l|}
\hline Business model building block & Description \\
\hline Value Proposition & $\begin{array}{l}\text { Provides a complete overview of all products and services of the } \\
\text { company and value that company offers to its customers }\end{array}$ \\
\hline Target Customer & Depicts the segments of customers a company wants to offer value to \\
\hline Distribution Channel & Describes the ways in which company gets in touch with its customers \\
\hline Customer Relationship & Explains the connection between the company and its customer segments \\
\hline Key Activities & Explains the way in which resources and activities are connected \\
\hline Key Resources & $\begin{array}{l}\text { Defines the competencies necessary to execute the company's business } \\
\text { model }\end{array}$ \\
\hline Key Partners & $\begin{array}{l}\text { Portrays the network of cooperative agreements with other companies } \\
\text { necessary to efficiency offer and commercialize value }\end{array}$ \\
\hline Cost Structure & $\begin{array}{l}\text { Sums up the monetary consequences of the means employed in the } \\
\text { business model }\end{array}$ \\
\hline Revenue Model & $\begin{array}{l}\text { Describes the way a company makes money through a variety of revenue } \\
\text { flows }\end{array}$ \\
\hline
\end{tabular}

Source: Osterwalder et al. (2005) and Osterwalder and Pigneur (2010)

\section{MARKET ORIENTATION AND BUSINESS MODELS OF NPOS}

Two types of organizations create the boundaries of the corporate landscape. On the one side of the spectrum, profit-oriented companies exist, with the purpose of maximizing shareholder value (in most cases, by maximizing companies' profits). On the other side, nonprofit organizations are set to achieve social and environmental objectives. Presented in this way, nonprofit organizations appear to be the antipode to profit-oriented businesses. However, this perspective may be misleading, since forprofit and nonprofit organizations may share more similarities than the abovementioned description implies. Maiere et al. (2016) argue that the phenomenon of NPOs becoming business-like has been analyzed in the academic literature since the 1980s. The notion of being business-like includes three dimensions: business-like rhetoric (e.g. narratives, visual communication), business-like organization of NPO's core and support processes (e.g. changes in the
NPO's governance structure to be more similar to the corporate model or becoming market-oriented in building relationships with stakeholders), and business-like goals (e.g. setting their goals in monetary terms or increasingly relying on sales revenues). Reasons for NPOs becoming business-like are visible on the organizational level, as well as in the context of the organization's environment. Examples of organizational factors that serve as an incentive to NPOs to operate in a business-like manner are board characteristics, organizational culture and field of activity, while environmental factors can be found primarily in civic, economic and political conditions the NPOs operate within.

However, not all scholars have a positive attitude towards introducing business practices into the nonprofits (Eikenberry and Kluver, 2004). At the core of their argument lies the fact that market-oriented models place little or no value on democratic ideals, such as fairness and justice, which may hinder the potential of nonprofit organizations to create and maintain a strong civil 


\section{Journal of Contemporary Management Issues}

society. As a result, nonprofit organizations are switching their focus from long-term issues (such as addressing a specific social problem, serving a particular social group or promoting minority rights) to short-term goals, such as generating commercial revenues, addressing competition or managing risk. Eikenberry and Kluver (2004) advise that nonprofit organizations should primarily keep their role of social service providers and builders of social capital, regardless of (predominantly financial) benefits of a market-oriented approach. Sargeant and Shang (2010) confirm that nonprofits should position themselves as organizations that follow their vision and mission, rather than focus solely on financial measures, since donors and partners are actually interested in what organization can accomplish and how it can contribute to the society.

Studies of business models in the nonprofit sector are scant. Research that touches on nonprofit business models aims to illuminate some of the complexities and idiosyncrasies that surround the ways nonprofit organizations operate and create value, rather than to propose a comprehensive framework for analyzing their business models. Empirical study on the nonprofit business model was conducted within the media industry - more specifically, within the periodicals publishing segment, in which nonprofits make up a large share (Maguire, 2009). The results suggest that aiming to find a single nonprofit business model may be a futile attempt, since multiple available business models can be found, even within a relatively narrow segment of nonprofit periodical publishers. Almost each aspect of the nonprofit business model has been placed under scrutiny from customers, donors, competitors and other stakeholders, which puts additional pressure on nonprofits to sustain stability in their operations and find the optimal mix of revenue streams. Wolff and Schlesinger (1998) looked at differences in hospital care services, provided by for-profit and nonprofit hospitals, under the different levels of competition. Their study showed that, in times of increased competition, nonprofit hospitals were more willing to admit uninsured patients and act in line with their social responsibility, but the sustainability of their operations was endangered by the high cost of care. On the other hand, forprofit hospitals were less sensitive to cost of care, but also provided less access to hospital care for those who were underinsured. The implication of these and similar studies point to the existence of internal factors (related to, for example, cost and risk management) and external factors (e.g. competition, government regulations) that put nonprofit organizations in trade-off situations, in which they have to choose between fulfilling their social purpose and acting in accordance with economic interests.

From the entrepreneurship perspective, nonprofit organizations serve an important role in national, as well as global economy. Morris et al. (2011) explored the entrepreneurial orientation in the nonprofit sector and found that social purpose leads to a set of processes and outcomes that are more complex and multifaceted than those in for-profit organizations. Entrepreneurial behavior of nonprofits incorporates the same dimensions as in for-profit context (i.e. innovativeness, proactiveness and risk taking), but it should be examined from both perspectives: social or mission-centric, as well as commercial or financial.

\section{METHODOLOGY}

Empirical part of the study is based on a research design, adapted from a multiplecase deductive study (Dul and Hak, 2008) 
that incorporates a comparison of business model components (Osterwalder and Pigneur, 2010), in order to identify common or divergent patterns. A group of ten nonprofit organizations was selected as a convenient sample, representing the population of nonprofit organizations in Croatia. The selection of nonprofit organizations was based on a number of criteria. First, to ensure that the organization has reached an adequate level of stability and maturity in their structure and operations, the minimum age acceptable for this study was set to four years. Second, to increase the heterogeneity of the sample, the preselected organizations had to be devoted to serving distinct social groups or subjects (e.g. minorities, youth, people with certain disabilities, children without parental care, small and mediumsized businesses, abandoned animals, etc.) and have a different reach, ranging from local to national. Third, the organizations had to vary in terms of size (measured in number of employees) and age. Finally, the organizations had to be geographically dispersed. General information about nonprofit organizations included in the study is given in Table 3.

Table 3. Sample characteristics

\begin{tabular}{|c|c|c|c|}
\hline Case & Mission/vision & $\begin{array}{l}\text { Number of } \\
\text { employees }\end{array}$ & $\begin{array}{l}\text { Years in } \\
\text { operation }\end{array}$ \\
\hline A & To improve and enhance the quality of life in eastern Croatia. & 5 & 12 \\
\hline B & $\begin{array}{l}\text { To provide temporary shelter and medical care for rescued dogs for the } \\
\text { purpose of finding them permanent new homes, to educate about and to } \\
\text { promote animal rights and protection, as well as vegan lifestyle. }\end{array}$ & 10 & 10 \\
\hline $\mathrm{C}$ & $\begin{array}{l}\text { To help young people improve the quality of life, find opportunities and } \\
\text { make informed choices. }\end{array}$ & 9 & 21 \\
\hline $\mathrm{D}$ & $\begin{array}{l}\text { To build and promote a networked platform of creative industries } \\
\text { stakeholders and to improve scientific research in social and humanistic } \\
\text { sciences. }\end{array}$ & 0 & 5 \\
\hline $\mathrm{E}$ & To build a society grounded in peace culture. & 7 & 27 \\
\hline $\mathrm{F}$ & $\begin{array}{l}\text { To offer psychosocial help to children, young people and their parents } \\
\text { through creative, educational and therapeutic content in order to improve } \\
\text { the quality of their lives. }\end{array}$ & 1 & 4 \\
\hline $\mathrm{G}$ & $\begin{array}{l}\text { To support children and young people in learning life skills necessary for } \\
\text { personal development and independent life. }\end{array}$ & 23 & 18 \\
\hline $\mathrm{H}$ & $\begin{array}{l}\text { To promote sustainable social, economic, cultural and environmental } \\
\text { empowerment and community building, actively respond to the needs of } \\
\text { citizens, and in particular provide support to socially vulnerable groups } \\
\text { that includes the social life of the local community. }\end{array}$ & 7 & 26 \\
\hline I & $\begin{array}{l}\text { To inspire and stimulate active enrollment of citizens in the development } \\
\text { of volunteerism and civil society. }\end{array}$ & 7 & 13 \\
\hline $\mathrm{J}$ & $\begin{array}{l}\text { To influence the public and political environment and promote the role of } \\
\text { entrepreneurship and the sector of small and medium-sized companies in } \\
\text { development of the Croatian economy. }\end{array}$ & 2 & 18 \\
\hline
\end{tabular}




\section{Journal of Contemporary Management Issues}

The data collection process included semi-structured interviews with managers and leaders of ten nonprofit organizations operating in Croatia. To reduce the influence of personal biases of researchers, the interview structure was based on previous studies on business models, the interviews were recorded and subsequently transcribed and analyzed by each author. To reduce interviewer interference during the conversation, most of the questions were open-ended and required a comprehensive response (e.g. "What resources are fundamental for the service that you provide?" and "How do you ensure the sustainability of your activities?"). Each interview lasted between 60 and 120 minutes. In addition to primary data, the analysis included information collected from official web sites and formal reports of the selected NPOs.

The analysis started with a comparison of business model components across cases (first conducted individually by each author and then collectively), followed by aggregation of similarities and differences among preselected organizations.

\section{ANALYSIS OF NPO BUSINESS MODELS IN CROATIA}

A minority of interviewees were familiar with the term "business model" (only one interviewee was conceptually familiar with the Osterwalder and Pigneur's framework for assessing business models), yet they were all able to describe the components of what they perceive as the business model of their nonprofit organization. The first section of the interview included questions about trends that have influenced the organization on a strategic, as well as on operational level. Weak government regulations related to the status of nonprofit organizations, coupled with the failure to comply with the law are threats, which are, to a different extent, present in all interviewed organizations. In line with that, NPO leaders have identified a lack of understanding and transparency, coming from supporting governmental institutions, as well as an increase in administrative burden that forces NPOs to devote too much of their resources to administrative work, as opposed to fulfilling their mission. Furthermore, nonprofits that rely heavily on projects to fund their operations have mentioned a decline in government funding as a big threat to their existence. To overcome this obstacle, NPOs either modify their mission to make a better candidate in competing for EU and national funding, or switch to a more business-like approach that sometimes makes them compromise the role of social service provider. Case I, which operates as a volunteering centre, has highlighted the fact that the popularization of the term "voluntarism" has led to an increase in programs that offer such opportunities. Ultimately, this has strengthened the competition in applying for funding and made them consider changing their mission and vision, in order to survive.

In terms of value proposition, nonprofit organizations offer a relatively small number of distinct products and services (e.g. counselling, education programs and workshops), and they are project-related in many cases (implying that, once the project is over, service offer may not continue). Not all NPOs have registered commercial activities (selling products and services, with the aim of generating revenue). Moreover, some of them are intentionally trying to avoid commercial activities, by offering their products in exchange for donations. One of the reasons for hesitating to "turn commercial" may be the belief that commercial activities will distract them to fulfill 
their social mission, due to consuming too many of their resources.

Target customers and key partners are business model components that sometimes overlap. Two NPOs from the sample perceive their donors as both customers and partners (Case A, a foundation, and Case J, a think-tank). However, they are not the only ones who actually have donors as their customers, but are the only one who think of them in that way. Others perceive donors as partners (not the buyers of their product or service), and target group as their customers (consumers of their products or services). Besides, only NPOs with a large target group are likely to divide their customers in segments.

Other business model components, in which NPOs demonstrate different practices are the revenue model and the cost structure. On the one hand, some NPOs rely almost solely on donations and project funding. In most cases, the higher the portion of funds coming from projects, the higher the portion of variable costs. On the other hand, some NPOs are using their commercial activities as the main source of funding (more than $50 \%$ of financial resources generated by selling their products and services) and their business models are overall closer to business models of social enterprises and profit-oriented companies.

Similarities among NPOs can be found in the following domains. All NPOs have highlighted that personalized relationships and direct contact with partners and customers represent the only possible approach to doing business. Furthermore, human capital is mentioned as the most important resource in every NPO. In addition to people, their expertise and networks, nearly half of the sample has nominated financial resources to be crucial for sustainability of their business model. Finally, reputation and full transparency of every activity also contribute to the success of several NPOs.

\section{IDENTIFYING AND OVERCOMING CHALLENGES OF ESTABLISHING A SUSTAINABLE NPO BUSINESS MODEL}

The need for a shift in performance of nonprofit organizations is more visible than ever. The growing changes in technology, values and demands require a new approach from NPOs in managing their organizations and in leading and managing social change. Although nonprofit organizations are mostly shaped by their mission and the needs of their stakeholders, the current and upcoming trends will substantially change the way they achieve their impact. Hartnett and Matan (2015) state several issues that NPOs must consider if they want not only to survive, but rather to have a more significant social engagement. First of all, substantial change in leadership is necessary, among both executives and board members of organizations since leaders with an authoritative approach will not be as successful in the future as they were in the past. Millennials, as a new and the largest generation in a workforce, want a sense of purpose in their work and nonprofits might be just the perfect place for them to achieve that. However, the leaders of the future will have to become even more flexible then they have been. They need to inspire, build a participatory and flexible surrounding and create passion among all of their followers. On the other hand, board roles should also be significantly reconsidered. A board member should be more than just a standing committee, they should be more engaged and more focused on their own 


\section{Journal of Contemporary Management Issues}

accomplishments and impact within the organization (Hartnett and Matan, 2015). Croatian NPOs have yet to answer this challenge. As seen in the analysis, human capital is the most important resource in every NPO. Their performance depends on the expertise of employees, volunteers and board members. Although NPOs are aware of the generational shift in workforce, most of them think that a nonprofit organization for Croatian youth is still not an attractive workplace (due to insecurity, perception about the low income and inability for job promotions). Also, although the board members in most NPOs are the main decision makers, their know-how is far less utilised than their know-who. However, NPOs are aware of their potential and are striving to involve them to a greater extent in their future performance and activities.

NPOs are a catalyst of social change and they usually have practical and creative solutions to many social problems. Still, the biggest challenge most of them have is lack of resources, especially financial, and thus their inability to develop sustainable performance. In order to reduce this barrier, Hartnett and Matan (2015) suggest for NPOs to move from traditional funding and donor retention. Instead, they should embrace new funding sources that started to have serious effect on fundraising efforts: a) social media - with its affordable means of connecting citizen philanthropists and engaging them with the work of the nonprofit; b) crowdfunding - a way for NPOs to effectively manage the opportunity to connect with individual donors and generate a buzz across a vast audience; c) virtual initiatives - adding a virtual component to a traditional event (e.g. virtual ad journal) - an opportunity for conscious NPOs to use anything but paper to display good will and congratulatory ads; d) reverse auctions items do not go to the winning bidder but rather are purchased on behalf of the organization thus helping NPOs quickly generate cash for much needed supplies; e) corporate support - to get and keep the attention of corporate donors NPO leaders will have to do a much better job in demonstrating and documenting their economic and social impact while offering concrete evidence that they are meeting the society's needs. Croatian NPOs are aware of the need to move beyond donations and project funding. However, most of them do not want to engage in any commercial activities since they think it might significantly shift their attention from their social mission. Thus, suggested funding sources actually might be a good start for nonprofits to promote their social value without losing themselves in the attempts to maintain organizational sustainability.

In order to be efficient and successful NPOs need to improve strategic and operational aspects of their performance. Hartnett and Matan (2015) argue that beside moving from old-fashioned ways of raising money towards selling their products and/or services or embracing new sources of funding they need to team up with others on a similar path with closely related goals (working together with government, donors, academic and other supporters on achieving mutually beneficial results). According to Smith and Phillips (2016), that requires nonprofits to develop business models responsive to heightened expectations on transparency and accountability. This, however, is not an easy task for nonprofits as they, according to the authors, face difficulty in creating collaborative relationships due to a lack of resources and/or personal negotiation skills.

New technology actually brings many new opportunities for nonprofits. Because of their social mission, NPOs are not as 
prone to marketing activities as profit organizations are. However, new technology is enabling easier and quicker access towards their shareholders, via interesting, inexpensive and efficient platforms (blogs, social media, YouTube, etc.). E.g., a video shared on social networks generates $1200 \%$ more shares than text and images combined, while viewers retain $95 \%$ of the message, when watching a video, compared to $10 \%$, when reading a text message (Ibrišević, 2018). Croatian NPOs do not use technology to such an extent and still consider individualized personal approach as the most transparent and most efficient way of communicating their social value.

The current way of living and working had a major impact on what seemed to be the most stable component of nonprofit performance - engaging volunteers. Hartnett and Matan (2015) show two sides of the coin. On the one hand, volunteers have become more demanding that NPOs show effectiveness, legitimacy, trustworthiness and integrity. On the other hand, time has become a scarce resource and many potential volunteers find themselves trying to balance between high-pressured jobs and having a good quality of their private life. Nonprofits, according to these authors, need to be much more strategic in order to make volunteerism more relevant, meaningful and fun for future generations of volunteers.

The challenges, changes and trends should not be taken for granted. NPOs should approach them strategically and consistently. Given the growing emphasis on the importance of socially responsible behavior of all actors of society, the nonprofit sector will become an even more important mediator in maintaining social development and achieving a positive social impact for their communities.

\section{CONCLUSION AND IMPLICATIONS}

In line with previous research, this study has confirmed the heterogeneous nature of the non-profit sector. Making simplistic generalizations about its business models may be a dangerous venture and not necessarily lead to a greater understanding of the field. While the business model framework reflects the way a company generates revenues, financial results are not the only desirable outcome, nor the most important goal that NPOs want to achieve. Therefore, the business model concept should reflect those characteristics of NPOs that are representative of most or all nonprofits. On a higher level, the primary concern of NPOs is the influence they are achieving in a local community or broader society. The focus is not on the profits, but rather on social or environmental benefits. Thus, the main indicators used for assessing success of NPOs are measuring their influence, not the financial results.

This study has applied qualitative research design to assess the applicability of the main components of the business model framework to nonprofit organizations. As a result, authors provide suggestions for conceptual modification of the business model framework that was initially developed for for-profit businesses. Findings point to several specifics of NPOs' business models. First, the landscape of stakeholders, with a high interest in NPOs' operations and a high influence on NPOs' overall success, is different from the for-profit business landscape. In addition to customers/target groups and key partners, a new component of business model is the relationship with donors who can be, in case of many nonprofit organizations, regarded as customers (buyers of a service or a product provided by the NPO) and partners (important source 


\section{Journal of Contemporary Management Issues}

of funding). Second, depending on the predominant source of funding and predictability of cash inflows, NPOs have different cost structures. Those with predictable funding streams have, on average, a higher portion of variable costs. Finally, results point to some similarities, present across all NPOs in the sample. Human and social capital is recognized as the most important resource of all NPOs in the study, with a special emphasis on the network of relationships. Personal approach is perceived as the best way to reach customers, partners and donors. Finally, transparency is a highly valued virtue and several NPOs described it as the foundation for creating competitive advantage.

The main weakness of the research method, applied in this study, is its limited potential for generalization of the findings. However, the study points to new research questions that direct the focus of prospective studies. First, nonprofits are building their financial plans in two different ways. Organizations that strategically approach their donors and tenders are completely mission-driven, while the other group opportunistically follows the sources of finance and it is ready to step out from the mission and vision area (they are describing their approach as creative toward tenders and donors). Second, attitudes toward incorporating commercial activities in the business model (selling products and services and competing with for-profit and other nonprofit organizations) are quite diverse and make a significant influence on the revenue stream and business model overall. Larger samples may help increase our understanding of the main drivers that direct decisions of NPO leaders in this regard.

\section{References}

1. Alfirević, N., Pavičić, J., Najev Čačija, Lj. (2014). Performance of non-profit organizations: Empirical contrasts between privately and publicly funded Croatian humanitarian organizations. Economic annals 59: 115-129.

2. Afuah, A., Tucci, Christopher L. (2003). Model of the Internet as Creative Destroyer. IEEE Transactions on engineering management 50

3. Amit, Raphael, and Zott, Christoph. 2001. Value Creation in E-Business. Strategic Management Journal 22: 493-520

4. Dolnicar, S., Lazarevski, K. (2009). Marketing in non-profit organizations: an international perspective. International Marketing Review. Vol. 26 No. 3, pp. 275-291. https://doi. org/10.1108/02651330910960780

5. Dul, J., Hak, T. (2008). Case study methodology in business research. Amsterdam: Elsevier,

6. Eikenberry, Angela M.; Kluver Drapal, Jodie. 2004. The marketization of the nonprofit sector: civil society at risk? Public administration review 64: $132-40$

7. Eriksson, H.-E. (2000.) Business modelling with UML. New York: Penker, Magnus, 1-12

8. Hamel, G. (2000.) Leading the revolution. Boston: Harvard Business Press

9. Hartnett, B., Matan, R. (2015.) What will Nonprofits of the Future Look Like: What's coming in the Next Decade. https:// sobelcollc.com/whitepapers/ what-will-nonpro $\% \mathrm{EF} \% \mathrm{AC} \% 81$ tsfuture-look-what $\% \mathrm{E} 2 \% 80 \% 99$ s-coming-next-decade (accessed on 15 April 2019) 
Management, Vol. 25, 2020, No. 2, pp. 181-194 J. Perić, A. Delić, M. Stanić: EXPLORING BUSINESS MODELS OF NONPROFIT...

10. Hedman, J., Kalling, T. (2003.) The business model concept: theoretical underpinnings and empirical illustrations. European Journal of Information Systems 12: 49-59

11. Helmig, B., Jegers, M., Lapsley, I. (2004.) Challenges in Managing Nonprofit Organizations. Voluntas: International Journal of Voluntary and Nonprofit Organizations, 15: 101-116

12. Ibrišević, I. (2018.) 8 Fundraising Trends for 2018: Looking Ahead. https://donorbox.org/nonprofit-blog/8fundraising-trends-2018/ (accessed on 15 April 2019)

13. Konczal, E. F. (1975.) Models are for managers, not mathematicians. Journal of Systems Management 26: 12-15

14. Linder, J., Cantrell, S. (2000.) Changing Business Models: Surveying the Landscape. Cambridge, MA, Accenture Institute for Strategic Change

15. Magretta, J. (2002.) Why Business Models Matter. Harvard Business Review 80: 86-92

16. Maguire, M. (2009.) The nonprofit business model: Empirical evidence from the magazine industry. Journal of Media Economics 22: 119-33.

17. Maier, F., Meyer, M., and Steinbereithner, M. (2016.) Nonprofit organizations becoming business-like: A systematic review. Nonprofit and Voluntary Sector Quarterly 45: 64-86.

18. Morris, M. H., Webb, J. W., Franklin, R. J. (2011.) Understanding the manifestation of entrepreneurial orientation in the nonprofit context. Entrepreneurship Theory and Practice 35: 947-71.

19. Najev Čačija, Lj. (2016.) The nonprofit marketing process and fundraising performance of humanitarian organizations: Empirical analysis. Management: Journal of Contemporary Management Issues: 21: $1-25$.

20. Osterwalder, A., Pigneur, Y. (2010.) Business model generation: A handbook for visionaries, game changers, and challengers. Hoboken, New Jersey: John Wiley \& Sons, Inc,

21. Osterwalder, A., Pigneur, Y., and Tucci, C. L. (2005.) Clarifying business models: origins, present, and future of the concept. Communication of the Association for Information Systems 15: $1-40$

22. Sargeant, A., and Shang, J. (2010.) Fundraising principles and practice, John Wiley and Sons, New Jersey

23. Smith Ratgeb, S., Phillips, S. D. (2016.) The Changing and Challenging Environment of Nonprofit Human Service: Implications for Governance and Program Implementation. Nonprofit Policy Forum 7: 63-76

24. Suykens, B., De Rynck, F., \& Verschuere, B. (2019.) Nonprofit organizations in between the nonprofit and market spheres: Shifting goals, governance and management? Nonprofit Management and Leadership 29: 623-636

25. Teece, D. J. (2010.) Business Models, Business Strategy and Innovation. Long Range Planning 43: 172-94

26. Timmers, P. (1998.) Business models for electronic markets. Electronic markets 8: 3-8

27. Treacy, M., Wiersema, F. (1997.) The discipline of market leaders: choose your customers, narrow your focus. Dominate Your Market, AddisonWesley, Readings, Massachusetts.

28. Williamson, O. E. (1980.) Organizational innovation: the 


\title{
Journal of Contemporary Management Issues
}

transaction-cost approach. University of Pennsylvania, Center for the Study of Organizational Innovation.

29. Wirtz, B. (2011.) Business model management, Design-Instruments-Success Factors. Gabler, Wiesbaden.

30. Wirtz, B., Kleineicken, A. (2000.) Geschaftsmodelltypologien im Internet. Wirtschaftswissenschaftliches Studium 29: 628-36
31. Wolff, N., Schlesinger, M. (1998.) Access, hospital ownership, and competition between for-profit and nonprofit institutions. Nonprofit and Voluntary Sector Quarterly 27: 203-36.

32. Yunus, M., Moingeon, B., LehmannOrtega, L. (2010.) Building social business models: Lessons from the Grameen experience. Long Range Planning 43: 308-25.

\section{ANALIZA POSLOVNIH MODELA NEPROFITNIH ORGANIZACIJA}

\begin{abstract}
Sažetak
Poslovni modeli se obično koriste za opis kako poslovni subjekti održavaju svoju konkurentsku prednost, pružaju kupcima veću vrijednost i ustrojavaju bolju suradnju s poslovnim partnerima. Dok postoji bogata literatura o primjerima najbolje prakse za profitne subjekte, neprofitne se organizacije rijetko promatraju i uspoređuju korištenjem koncepta poslovnog modela. Neprofitne se organizacije uglavnom analiziraju kao vođene misijom, zbog čega je njihova poslovna strana uglavnom zanemarena. Uspjeh neprofitnih organizacije obično se mjeri njihovim utjecajem u zajednici, što čini djelovanje istih dinamičnim $i$ veoma ovisnim o poslovnom ekosustavu. Cilj je ovog rada utvrditi specifičnosti poslovnih modela u neprofitnom sektoru, kako bi se utvrdilo koliko dobro neprofitne organizacije komuniciraju kupcima (korisnicima) svoju ponudu vrijednosti, što ih razlikuje od drugih organizacija i što rade, s ciljem razvoja uspješne i održive organizacije. U empirijskoj se studiji analizira 10 hrvatskih neprofitnih organizacija. Za opis i usporedbu njihovih poslovnih modela koristi se koncepcija platna poslovnog modela. Rezultati predstavljaju dobru osnovu za razumijevanje učinka neprofitnih organizacija te mogu poslužiti kao okvir za donošenje specifičnih politika i programa, namijenjenih razvoju neprofitnih organizacija.
\end{abstract}

Ključne riječi: poslovni modeli, neprofitne organizacije, društvena misija, ponuda vrijednosti, studija slučaja 